\title{
Presidential Second Terms Are Not Cursed, But the Timing of Reelection Has Become So
}

\author{
Rick LaRue
}

\begin{abstract}
Presidential second terms have been found wanting at least since Ulysses Grant held office. They also feature midterm elections that repudiate a president reelected just two years earlier. Past ideas for mitigating such weaknesses have focused on revisiting the Twenty-second Amendment's two-term limit or reviving the perennial proposal for a single six-year term. Instead, consideration should be given to retaining the two-term structure but changing each term's length. Terms of six followed by three years would better reflect their respective value and likely lead to improved governance (electoral synchronicity would be maintained by changing House terms to three years). Prospective benefits include structuring the presidency to match how the public's relationship to the office has evolved; reducing a reelected president's lame-duck status from half of his or her presidency to one-third; making pursuit of reelection other than automatic; strengthening second terms by eliminating their midterm elections; and reducing the proportion of campaigning relative to governing.
\end{abstract}

Keywords: second-term curse, lame-duck presidencies, presidential term lengths, permanent campaign, constitutional amendments, presidential reelection

\section{INTRODUCTION}

$\mathbf{L}$ AMENTS ABOUT THE DIMINISHED QUALITY of presidential second terms have grown common in the decades since the 1947 passage and 1951 ratification of the Twenty-second Amendment limiting presidents to two terms. Particularly as a two-term presidency wanes, doubts about the second term's efficacy mount, and talk of second-term itches, ${ }^{1}$ curses, ${ }^{2}$ blues, ${ }^{3}$ and lame ducks ${ }^{4}$ grows louder. A second-term curse may not exist, but evidence accumulates in each presidency that the second term is less productive than the first. Such results can be "di-

Rick LaRue worked for 40 years at Washington, DC, nonprofit organizations, including the Eisenhower Institute, American Society of International Law and, most recently, the Center for Responsive Politics.

(C) Rick LaRue, 2018; Published by Mary Ann Liebert, Inc. This Open Access article is distributed under the terms of the Creative Commons Attribution Noncommercial License (http:// creativecommons.org/licenses/by-nc/4.0/) which permits any noncommercial use, distribution, and reproduction in any medium, provided the original author(s) and the source are cited. sastrous," as presidential historian Lewis Gould notes, ${ }^{5}$ or merely the expected result of a structure in which second terms, by their very nature, have to follow first terms that are successful by at least one consequential measure-they led to the incumbent's reelection. Perhaps most emblematic of secondterm weakness is the "reelection paradox," identified by Kevin Phillips in 1984, in which a president wins reelection, often easily, only to see his or her power weakened two years later by congressional midterms

\footnotetext{
${ }^{1}$ Kevin Phillips, Reelection Paradox: Landslide and Loss of Power, Christian ScI. Mon. Nov. 2, 1984, <http://www .csmonitor.com/1984/1102/110212.html>.

${ }^{2}$ See, e.g., Colleen J. Shogan, The Sixth Year Curse, 36 Pres. STUD. Q. 89, 89-101 (Mar. 2006).

${ }^{3}$ Second Term Blues: How George W. Bush Has GovERNED (John C. Fortier and Norman J. Ornstein eds., 2007).

${ }^{4}$ See, e.g., Shogan, supra note 2; see also Jeremy Paul, If It Quacks Like a Lame Duck, Can It Lead the Free World?: The Case for Relaxing Presidential Term Limits, 43 ConN L. REV. 1097 1099-1100 (May 2011).

${ }^{5}$ Lewis L. Gould, The Modern American Presidency xv (2nd ed. 2009).
} 
that place or more firmly place both houses in the hands of the opposition. ${ }^{6}$ Not only has this paradox become predictable (with just one understandable exception), but its impact on second terms also has become more pronounced and debilitating, in part due to the emergence of the permanent campaign.

In this article, I will argue that an alternative presidential term structure would better reflect the relative value of first and second terms and would also be likely to provide desirable governing benefits. This thought experiment calls for a new legal foundation that would retain the traditional and nowconstitutional two-term limit for the presidency but would vary the terms' lengths. The main premise for doing so is that it no longer makes sense to give the second term equal value-length - as the first term since reelection after four years is producing predictably poorer quality outcomes and may no longer fit with voting behavior. Specifically, this proposal would establish a six-year first term and a three-year second term. Electoral synchronicity would be preserved by changing terms in the U.S. House of Representatives to three years and adjusting Senate elections to be for half the seats every three years rather than for one-third of the body every two. Before elaborating on this structure's potential advantages, I will review recent and historical consideration of the need for and value of second terms; summarize the persistent problems that have earned second terms their "lame duck" description; examine attempts to analyze second-term decline systematically; and assess the alternative structures that have been proposed, particularly the oft-made recommendation for a single six-year term. ${ }^{7}$ Such review will lead to my observation that the critical inadequacy can be found in the timing of presidential reelection after four years, followed by my case for reelection after six years, but only for an additional three years. I will also address areas for further research, the impact of the Trump presidency and the hurdle of amending the U.S. Constitution.

\section{SECOND TERM VALUE: RECENT AND HISTORICAL VIEWS}

Winning a second term has become, if not predictable, the presidential norm. Four of the last five presidents have done so, as have eight of the last eleven who sought one. Second terms have proved, however, to be of diminished value compared to their corre- sponding first terms. Analysts of the presidency place a reelected incumbent's struggles to lead the country in the context - causal or not-of his or her inability to run for another term. Other factors of course contribute to the actual or perceived difficulties that a reelected incumbent faces (e.g., the economy), as I will address below, but the lame-duck quality of presidential second terms shapes media and other contemporary interpretations of presidential leadership and is a widely recognized if not fully accepted phenomenon. As Michael Korzi noted, "If political observers and especially media and congressional elites accept the lame duck syndrome as axiomaticand importantly, act upon this assumption-the syndrome is accentuated and intensified and becomes, over time, more and more applicable to second-term presidents." ${ }^{8}$ Furthermore, even those scholars and quantitative analysts who have yet to find sufficient systematic evidence to conclude definitively that a second-term curse exists nonetheless acknowledge the diminished value of second terms. ${ }^{9}$

Commentaries during Barack Obama's second term are indicative. Less than one year after his reelection, for example, Jonathan Zimmerman argued on the op-ed page of the Washington Post for strengthening second terms by repealing the Twenty-second Amendment, ${ }^{10}$ followed two months later by Thomas Cronin's defense of the amendment on the same page. ${ }^{11}$ Others suggested eliminating poorer-quality second terms entirely. In the Financial Times in the summer of 2014, Lawrence Summers complained

\footnotetext{
${ }^{6}$ Phillips, supra note 1.

${ }^{7}$ In 1988, Bruce Buchanan aptly called this proposal "the reform that just won't die." See Bruce Buchanan, The Six-Year One Term Presidency: A New Look at an Old Proposal, 18 Pres. Stud. Q. 129, 129 (Winter 1988).

${ }^{8}$ Michael J. Korzi, Presidential Term Limits in American History 161 (2011) (emphasis added).

${ }^{9}$ James R. Hedtke, Lame Duck Presidents-Myth or REAlty 152, 154 (2002); KorZI, supra note 8, at 161; Thomas E. Cronin, Presidential Term, Tenure and Reeligibility, in Inventing the American Presidency 84 (Thomas Cronin ed., 1989); Nate Silver, Is There Really a Second-Term Curse? N.Y. TIMEs, May 16, 2013, <http://fivethirtyeight.blogs .nytimes.com/2013/05/16/is-there-really-a-second-term-curse/>. ${ }^{10}$ Jonathan Zimmerman, End Presidential Term Limits, WASH. Post, Nov. 28, 2013, <https://www.washingtonpost.com/opinions/ end-presidential-term-limits/2013/11/28/50876456-561e-11e3ba82-16ed03681809_story.html>.

${ }^{11}$ Thomas E. Cronin, Term Limits Are a Check Against an American Cult of Personality, WASH. Post, Jan. 3, 2014, <https:// www.washingtonpost.com/opinions/term-limits-are-a-checkagainst-an-american-cult-of-personality/2014/01/03/270d30346374-11e3-aa81-e1dab1360323_story.html>.
} 
that our nation had lost four decades of presidential service due to a structure that produces lame-duck second terms. Even though his call for consideration of alternatives such as a single six-year term was noncommittal, he nonetheless hit upon the need for change when he concluded, "All reelected presidents expect to beat the second-term curse. None has." 12 Jeremy Paul did not wait for Obama's reelection to argue in 2011 that the Twenty-second Amendment is a "failed constitutional experiment" and that "each President elected for a second time since the adoption of presidential term limits has found his second term unfulfilling or worse." 13

But debates about the legal and structural issues of whether a president should stand for reelection or be restricted in his or her ability to continue in office are as old as the nation. The delegates to the Constitutional Convention vigorously argued over the selection process and length of service for the nation's chief executive. ${ }^{14}$ In the early and late nineteenth century, and again in the early and late twentieth century, support for a single, longer term emerged. At least 15 U.S. presidents have supported the idea of a single six-year presidential term, ${ }^{15}$ and amendments advocating such a structure were introduced 208 times between 1826 and 2009. ${ }^{16}$ A quick review of this history begins with the Constitutional Convention.

The gathering in Philadelphia in the summer of 1787 remains an iconic moment in U.S. history and government legal thought. Of interest in this case is the delegates' effort to blend diverse administrative and philosophical concerns over executive power. In particular, their search for agreement on the number and length of presidential terms proved a source more of contention than of consensus up to the convention's very end. From anti-federalists who believed "when annual elections end, tyranny begins," 17 to federalists who sought to give the chief executive the opportunity to provide stability in the service of the larger national interest, extensive debate occurred over the matters of term lengths and reeligibility. With regard to the former, no fewer than 60 votes were taken during the Convention. ${ }^{18}$ On June 1 , the delegates adopted a single seven-year term for the president, although he was to have been chosen by the Congress. ${ }^{19}$ Various other single-term lengths were considered, such as eight, eleven, fifteen, and twenty years. ${ }^{20}$ Ultimately, as the Convention neared its end, the matter was delegated to the Committee on Postponed Matters (also known as the Committee of Eleven). ${ }^{21}$ On Septem- ber 4 , the Committee offered its solution-fouryear terms with unlimited eligibility for reelectionwhich prevailed and was included in the final document proposed to the states on September $17 .^{22}$

The case for this structure was articulated in Federalist Papers 71 and 72 . The former addressed the value of the length of the term for attracting capable leaders and for providing independence in the office and stability in administration. ${ }^{23}$ The latter spoke of the benefits of reeligibility, notably to provide "the inducement to good behavior" on the part of the president and to enable the people "to prolong the utility of his talents and virtues." ${ }^{24}$ While this structure provided for an empowered chief executive who could serve as many four-year terms as he could win, age and health were thought to be naturally limiting factors. ${ }^{25}$ George Washington concluded his tenure as the first president after being reelected once and serving a total of eight years, but he opposed term limits. ${ }^{26}$ It was Thomas Jefferson who purposely did not pursue a third term, saying, "I should unwillingly be the person who ... should furnish the first example of prolongation beyond the second term of office." 27 He established a tradition that lasted until 1940.

${ }^{12}$ Lawrence Summers, Second-Term Presidents Cost America 40 Lost Years, Fin. Times, Aug. 10, 2014, <http://www.ft.com/ $\mathrm{cms} / \mathrm{s} / 2 / 74$ dacab2-1e3e-11e4-ab52-00144feabdc0.html\#axzz4 EGzdta9Z>.

${ }^{13}$ Paul, supra note 4, at 1099-1100.

${ }^{14}$ KorZI, supra note 8, at 13-37; HedTKE, supra note 9, at 1128; Am. Enterprise Inst. Legislative Analyses, Limiting Presidential and Congressional Terms 2-5 (1979); Thomas H. Neale, Congressional Research Service, Presidential Terms and Tenure: Perspectives and Proposals For Change 1-4 (Oct. 19, 2009).

${ }^{15}$ Buchanan, supra note 7 , at 129 .

${ }^{16}$ NeAle, supra note 14 , at 22.

${ }^{17}$ KorZI, supra note 8, at 16.

${ }^{18}$ Cronin, supra note 9, at 65.

${ }^{19}$ Max Farrand, The Framing of the Constitution of the United States 78 (1913); see also Am. EnTERPRISE InST., supra note 14, at 25.

${ }^{20}$ Am. ENTERPRISE INST., supra note 14, at 2.

${ }^{21}$ NeAle, supra note 14 , at 3.

${ }^{22} I d$.

${ }^{23}$ THE FEDERALIST PAPERS No. 71 (Alexander Hamilton).

${ }^{24}$ THE FEDERALIST PAPERS No. 72 (Alexander Hamilton), at 278 (ReadaClassic.com, 2010).

${ }^{25}$ KorZI, supra note 8, at 49 (citing Thomas Jefferson's views). ${ }^{26}$ Zimmerman, supra note 10.

${ }^{27}$ Caleb J. Halberg, Power and Time: Why Anti-Federalists Feared Lengthy Presidential Terms, DePaul U. Col. L. 9 (Dec. 15, 2010), at SSRN: <http://ssrn.com/abstract=1726182> or <http://dx.doi.org/10.2139/ssrn.1726182>. 
Proposals for a longer single-term presidency began to emerge early in the nineteenth century. The arguments in favor had their roots in anti-federalist thought, from support for "frequent elections and compulsory rotation" to fear that permitting the continuing service of a qualified leader "reeked of aristocracy." 28 Supporters of a single six-year term included such leaders as Chief Justice John Marshall and President Andrew Jackson. ${ }^{29}$ An amendment for a single six-year term was first proposed in Congress in $1826,{ }^{30}$ and Jackson persistently advocated for it in his annual messages to the Congress," 31 stating that presidents should be "beyond the reach of any improper influences." 32 (He did not, however, follow his own advice; he stood for and won reelection in 1832.)

Another wave of support for a single six-year term occurred in the late nineteenth and early twentieth centuries in response to concerns about the graft and corporate largesse that had emerged in the Gilded Age. ${ }^{33}$ The proposal earned support into the Progressive Era and was not merely an intellectual exercise; it became part of the Democratic Party platform in 1912, passed the Senate with more than a two-thirds majority in 1913 and prompted the new president, Woodrow Wilson, to repudiate his party's own platform and lobby the House to defeat it. ${ }^{34}$

Only once over the course of two and one-quarter centuries has the debate about the underlying legal structure of presidential terms risen to an actionable level. The Twenty-second Amendment limiting presidents to two terms was advanced and adopted because Franklin D. Roosevelt broke the twoterms-only tradition. The Amendment is striking because it is the sole constitutional change that did not move the country "toward greater democracy" 35 and "explicitly rejected" the Federalist argument "that a popular president could remain in office for life." ${ }^{36}$ Depending on one's partisan or philosophical views, FDR's third and fourth terms either validated the Federalist notion of continuing the service of a valued, desired president at a time of crisis (World War II) or represented a violation of the principle of rotation and offended people who found the notion of an indispensable leader elitist if not dictatorial. ${ }^{37}$ Ultimately, however, the rhetoric surrounding the Twenty-second Amendment's two-term limit and the votes for or against it were decidedly partisan. ${ }^{38}$ (And it bears noting that, prior to the 1947 vote, the Republican Party platform in 1940 called for term limits and, in 1944, revived the call for a single six-year term. ${ }^{39}$ ) Presidents elected starting in 1952 would be restricted to only two terms.

There was another flurry of consideration of a single six-year term from the mid-1970s through the mid-1980s, a period in which the civic-minded actively contemplated the structure of the presidency following the Watergate scandal and during the celebrations of the bicentennials of the Declaration of Independence and the U.S. Constitution. ${ }^{40}$ This period was notable, too, as it marked the end of a tumultuous period in U.S. presidential history, from the assassination of JFK to Watergate's aftermath. The Committee for a Single Six-Year Presidential Term was formed, led by co-chairs Griffin Bell, attorney general for Jimmy Carter; Herbert Brownell, attorney general for Dwight Eisenhower; William Simon, treasury secretary for presidents Nixon and Ford; and Cyrus Vance, secretary of state for Jimmy Carter. ${ }^{41}$ They claimed that "reelection pressures lie at the heart of our inability to manage complex, long-term national problems, domestic and international."42 In 1982, Cyrus Vance elaborated, saying that "the national interest would be better

\footnotetext{
${ }^{28} I d$. at $4-5$.

${ }^{29}$ Neil Peirce, Ford's Bipartisanship: How to Keep it Alive, Houst. Chron., Jan. 7, 2007, <http://www.chron.com/opinion/ outlook/article/Peirce-Ideas-to-help-keep-Gerald-Ford-s-1808226 .php> (referencing John Marshall's support for a single six-year term); AM. ENTERPRISE INST., supra note 14, at 11 (referencing Andrew Jackson's support of a single six-year term).

${ }^{30}$ Buchanan, supra note 7, at 129.

${ }^{31}$ KorZI, supra note 8, at 52.

${ }^{32} \mathrm{Am}$. ENTERPRISE InST., supra note 14 , at 11.

${ }^{33}$ KorzI, supra note 8, 58-72.

${ }^{34}$ Tom Wicker, Six Years for the President, N.Y. Times Mag. 3 (June 26, 1983), <http://www.nytimes.com/1983/07/31/magazine/ 1-six-years-for-the-president-069728.html>; The Jefferson Foundation, The Single, Six-Year Term for Presidents (1984), in Reforming American Government: The Bicentennial Papers of the Committee on the Constitutional System 171 (Donald L. Robinson ed., 1985).

${ }^{35}$ David Karol, Pro: Resolved, the Twenty-Second Amendment Should Be Repealed, in Debating the Presidency 50 (Richard J. Ellis and Michael Nelson eds., 2010).

${ }^{36}$ Sanford Levinson, An Argument Open to All: ReadING THE Federalist IN the 21st Century, 272 (2015).

${ }^{37}$ KorZI, supra note 8 , at $125-142$.

${ }^{38}$ HedTKe, supra note 9 , at 52-53.

${ }^{39}$ NeAle supra note 14 , at 13.

${ }^{40}$ Am. ENTERPRISE INST., supra note 14, at 11.

${ }^{41}$ Buchanan, supra note 7, at 129.

${ }^{42}$ Griffin Bell et al., For a One-Term, Six-Year Presidency N.Y. Times, Dec. 31, 1985, <http://www.nytimes.com/1985/12/31/ opinion/for-a-one-term-six-year-presidency.html>.
} 
served by Presidents who are not intent on being reelected." ${ }^{43}$ In addition to the usual arguments about the opportunity costs and debasing influences of campaigning, they cited Lyndon Johnson's assertion that serving a single term might prompt a president to act on a difficult problem rather than postpone doing so until after reelection. ${ }^{44}$

Meanwhile, the debate over term limits grew louder in Ronald Reagan's second term, as a vocal group of his supporters called for repeal of the Twenty-second Amendment so he could run again. ${ }^{45}$ The idea faded, no doubt influenced by Reagan's age in his last year in office (77). The idea of one six-year term also continued to percolate, but it, too, faded; polling on the single sixyear term during this period found 41 percent in favor in 1980 but declining to only a quarter in support in $1986 .{ }^{46}$ Arthur Schlesinger spoke for the prevailing view when he wrote that it was a "terrible idea ... at war with the philosophy of democracy" and "that the President's duty is not to ignore and override popular concerns but to acknowledge and heed them." 47

Since then, both ideas have emerged from time to time-scholars and columnists have continued to pen analyses, proposals, and queries-but without any active or organized political force. In particular, political scientists have attempted to determine if the lame-duck phenomenon can be empirically documented. Before turning to such analyses, I will provide a reminder about the consistently poorer quality of second terms and the reasons proffered for them.

\section{POORER SECOND TERMS AFTER WORLD WAR II AND A SUMMARY OF RECENT SCHOLARSHIP ABOUT THEM}

The structure of the presidency - two equal, fouryear terms if reelection occurs-is not the only factor contributing to comparatively poorer performance by modern presidents as an incumbent's tenure lengthens. For example, the more direct relationship between the president and the voters that emerged in the twentieth century, as analyzed by Jeffrey Tulis in 1987 (and revisited by him in 2017), has proved increasingly problematic. He described how presidents became responsive to a "second constitution" in the twentieth century, namely a "presidential leadership of popular opinion ... buttressed by several extra-constitutional factors such as the mass media and the proliferation of primaries as a mode of presidential selection." 48 Such leadership was "more deleterious than beneficial" and has led to more use of reactive "crisis politics." 49 With specific regard to the nomination process's contribution to difficulties with the modern presidency, Richard Pildes and Stephen Gardbaum recently elaborated on challenges stemming from the parties' nominees being determined by "a purely populist method" primaries and "a small dose of caucuses"-absent any "peer review" in use before the $1970 \mathrm{~s} .{ }^{50}$ And Jeremi Suri has described how recent presidents have faced actual or perceived declines in their service because, paradoxically, they seemingly have more power but face increased demands as a result. "Rising expectations of presidential power encourage unrealistic promises, followed by popular disappointment and perceptions of executive "weakness," he writes, noting that "the promise of the presidency always exceeds what is possible." 51 Finally, the simple passage of time is frequently the enemy of an elected leader, which naturally impacts the second term the hardest; Charlie Cook noted that "the novelty, energy, and excitement of newly elected presidents tends to dissipate in their second terms... and a level of fatigue starts to plague the relationship between a president and the electorate." 52

So the question is not whether a structural change can solve all these problems but whether it could

\footnotetext{
${ }^{43}$ Cyrus R. Vance, Reforming the Electoral Reforms, 1 YALE L. \& Policy Rev. 151156 (1982).

${ }^{44}$ Wicker, supra note 34 , at 7.

${ }^{45}$ Cronin, supra note 9, at 86; Zimmerman, supra note 10.

${ }^{46}$ Kathleen Weldon, The Public and the 22nd Amendment: Third Terms and Lame Ducks, Huff. Post, Aug. 11, 2015, $<$ http://www.huffingtonpost.com/kathleen-weldon/the-publicand-the-22nd-a_b_7967538.html>.

${ }^{47}$ Arthur Schlesinger, Jr., Against a One-Term, 6-Year President, N.Y. Times, Jan. 10, 1986, <https://www.nytimes.com/ books/00/11/26/specials/schlesinger-6year.html>.

${ }^{48}$ Jeffrey K. Tulis, The Rhetorical Presidency 18 (2017). ${ }^{49}$ Id. at 181 .

${ }^{50}$ Stephen Gardbaum and Richard H. Pildes, Populism and Democratic Institutional Design: Methods of Selecting Candidates for Chief Executive in the United States and Other Democracies, NYU L. REv. (Nov 3, 2017; Forthcoming, 2018). Available at SSRN: <https://ssrn.com/abstract=3064938>. ${ }^{51}$ Jeremi Suri, The Impossible Presidency: The Rise AND Fall of America's Highest Office xx and xv (2017).

${ }^{52}$ Charlie Cook, Six-Year Itch Plagues Presidents in Midterms, NAt. J.. Jan. 6, 2014, <https://www.nationaljournal.com/daily/ 2014/01/06/six-year-itch-plagues-presidents-midterms $>$.
} 
help mitigate them-enough to merit consideration of amending the Constitution. A quick summary of presidential second terms since World War II signals at least the desirability of such change. I begin with Harry Truman because, even though the Twenty-second Amendment, which he opposed, would have permitted his reelection in 1952, he chose to follow the tradition of the twoterm presidency ${ }^{53}$ (or sensed the unlikelihood of his reelection). His second term was dominated by an increasingly unpopular Korean War and the exposure of corruption in his administration, due in no small measure to his second term representing the fifth straight term of Democratic control of the executive branch. Dwight Eisenhower may have sustained his popularity during his second term, but it featured the resignation of his chief of staff in a scandal and two international embarrassments: the Soviet launch of Sputnik and the downed U-2 spy plane piloted by Gary Powers. Richard Nixon had Watergate, which led him to resign the presidency one and one-half years into his second term. Ronald Reagan and Bill Clinton, like Ike, preserved much of their popularity during their second terms, but their effectiveness and reputation were marred by the Iran-Contra and Lewinsky-impeachment scandals, respectively.

George W. Bush's second term included two divisive wars begun in his first term, mounting deficits, the failed government response to Hurricane Katrina, and the worst economic collapse since the Great Depression. Barack Obama's second term was actually marked by a slight rise in his popularity, likely fueled by favorable comparisons to his two prospective successors, Donald Trump and Hillary Clinton. Still, such second-term achievements as the Iran nuclear deal and the opening to Cuba were and remain controversial, and two major initiatives - the Trans-Pacific Partnership trade agreement and, particularly, the Merrick Garland nomination to the Supreme Court-were blocked because his opponents deferred action until after the election, classic moves against a lame-duck president.

This brief summary is not meant to suggest that presidents accomplish nothing in their second terms or that their functions as manager of the bureaucracy ${ }^{54}$ or chief-of-state administrator, ${ }^{55}$ particularly in foreign affairs, ${ }^{56}$ were not well or ably served in years five through eight. Rather, it simply reminds us how second terms are known more for diminished performance rather than for achievement. Scholars have examined this record and agree, even if they disagree about its extent or its causes. There are many reasons that could cause second-term problems that are not due to or related to the Twenty-second Amendment. Among those offered by David Crockett are administration fatigue, reelection hubris (thinking a mandate has been earned and overreaching) and "early leadership failure" (i.e., scandals occurring in the first term) ${ }^{57}$ John Fortier and Norman Ornstein included these reasons, but called fatigue "burnout," and added lack of new ideas, party infighting, and midterm losses to the list. ${ }^{58}$ Additionally, second terms by definition follow successful first terms; the president achieved some level of success to have been reelected. David Mayhew indirectly identified such factors for first-term success when he described categories of "plausible suspects" for incumbency advantage, albeit against a president's opponent at the time of reelection, but these factors also raise a high bar for incumbents to meet in their own second terms. Among them are voter attitudes (e.g., risk aversion and inertia) and "innately superior talent," or being "premium politicians within their contest class," which he considered the primary factor in creating a "selection effect" or bias against their opponents; ${ }^{59}$ such factors also can lead to high or higher expectations for themselves that are difficult to meet in second terms. Crockett adds that a president's reelection results from an evaluation of the first term rather than support for a second-term agenda, ${ }^{60}$ an example of approval by retrospective voting. ${ }^{61}$ Also, presidents tend to

\footnotetext{
${ }^{53}$ David McCullough, Truman 770-771 (1992).

${ }^{54} \mathrm{Se}$, e.g., Richard P. Nathan, The Administrative PresIDENCY (1983).

${ }^{55}$ Daniel C. Diller, Chief of State, in Guide to the Presidency, Third Edition, Vol. 1, 687-716 (Michael Nelson ed., 2002).

${ }^{56}$ ForTIER AND ORNSTEIN, supra note 3, at 5-6.

${ }^{57}$ David A. Crockett, "An Excess of Refinement": Lame Duck Presidents in Constitutional and Historical Context, 38 Pres STUD. Q. 707, 716-717 (December 2008).

${ }^{58}$ Fortier AND OrNSTEIN, supra note 3 , at 2-7.

${ }^{59}$ David R. Mayhew, Incumbency Advantage in U.S. Presidential Elections: The Historical Record, 123(2) PoL. ScI. Q. 201, 214-217 (2008).

${ }^{60}$ Crockett, supra note 57 , at 716 .

${ }^{61}$ Christopher H. Achens and Larry M. Bartels, Democracy For Realists: Why Elections Do Not ProDuce Responsive Government 90-115 (2016). See also Tulis, supra note 48, at 203.
} 
pick the low-hanging policy fruit in the first term, the converse of the above-cited reason LBJ offered in support of a longer single term. Finally, with specific regard to the second midterm election's role in contributing to relatively poorer secondterm performance, Colleen Shogan wrote in 2006 that the six-year itch was "an understatement" and instead was a "full fledged "curse." 62 She elaborated by describing three types of problems that have plagued presidential second terms for 150 years - scandals, weakened coalitions, and midterm electoral defeat - and indicating that each president from Grant to Clinton experienced at least two of the three. ${ }^{63}$ Thus, the first term is a tough act to follow. Particular reasons may be different for each president, as factors and circumstances will be idiosyncratic, which complicates straightforward comparisons of presidents' performance across two terms. But the reality of being perceived a lame duck remains.

Such near-universal recognition of reduced performance in second terms has led observers and analysts toward two main responses. The first is tolerance for and acceptance of, as Crockett describes, "a problem inherent in a republican system that allows for reelection." ${ }^{64}$ Second is a desire for stronger, empirical evidence to prove the "curse," or at least to better understand its genesis. In 2014, Daniel Franklin sought to quantify and measure certain variables of presidential activity to determine if the curse was real. He studied the presidencies from Eisenhower to Bush and examined, among other measures, use of the veto ("a tool of last resort for leaving presidents"), use of pardons and executive orders, presidential legislative support scores, the acceleration of the departure of top-level personnel, and declines in substantive diplomatic accomplishments. ${ }^{65} \mathrm{He}$ concluded that "it is probably the case that there is some kind of causal connection between the 22nd Amendment, divided governments, and lame duck presidencies, the mechanism being that more two-term presidencies lead to more second midterm elections that then result in more divided governments." ${ }^{66}$ James Hedtke, on the other hand, looked at similar variables in 2002, but only through the Clinton administration, and found no causal connection between the two-term limit and lame-duck presidencies; instead, he attributed any poorer second-term performance mostly to "partisan politics and exogenous events." 67
Tellingly, however, after asserting that "the lame duck syndrome ... is more myth than reality," Hedtke wrote that "maybe, the lame-duck syndrome defies empirical analysis." ${ }^{68}$ For four main reasons, this offhand observation is truer than he may have intended. First and foremost, while empirical analysis can inform our understanding of presidential performance, the "N" - the number of presidents-is simply too small to generalize about almost any results or find causation. Second, the variables examined are too interrelated and influenced by different things-which Hedtke acknowledged by elevating the role of exogenous factors - to make any conclusions that could be consistently applied across presidencies. Third, as Stephen Skowronek observed, timing issues, such as whether the incumbent's predecessor was of the same or different party, complicate any ability to draw comparisons. ${ }^{69}$ Finally, the political, economic, social, and international environments have been extraordinarily different for each and every president, as using the historical perspective to analyze presidencies would indicate. ${ }^{70}$ The economic, social, technological, and international circumstances Eisenhower faced in the 1950s were unlike those Reagan faced in the 1980s, which were unlike those Clinton faced in the 1990s, and so on.

Even data journalist Nate Silver tried to get to the bottom of the second-term curse. In 2013 he observed that presidential popularity consistently declined from the first to the second term; i.e., average presidential approval ratings were at $56 \%$ in year five, the first year of the second term, and declined to $42 \%$ by year eight. ${ }^{71}$ Although he admitted that this was only one measure and that the data set of presidencies since FDR was too small, he insisted on searching for a "systematic tendency"(emphasis in original) that would merit the characterization of a "curse," which he did not find. ${ }^{72}$

\footnotetext{
${ }^{62}$ Shogan, supra note 2 , at 89.

${ }^{63} I d$. at 90.

${ }^{64}$ Crockett, supra note 57 , at 720 .

${ }^{65}$ Daniel P. Franklin, Pitiful Giants: Presidents in Their Final Terms 28, 36, 46, 53-56, 91 (2014).

${ }^{66} I d$. at $25,171$.

${ }^{67}$ HedTKE, supra note 9, at 3, 214.

${ }^{68} \mathrm{Id}$. at 138.

${ }^{69}$ Stephen Skowronek, The Politics Presidents Make 33-45 (1993).

${ }^{70}$ Crockett, supra note 57, at 718 .

${ }^{71}$ Silver, supra note 9 (emphasis in original).

${ }^{72} I d$.
} 
What Silver and other empiricists may have missed is what Norman Ornstein called the "variety of mundane causes" that can produce a "sixth-year massacre." 73 Such factors do defy systematic analysis, as Hedtke suspected, and the reasons for any one second term to be poorer than its corresponding first term will vary from president to president. The factors involved do not lend themselves to becoming variables; they can neither be isolated nor accurately or consistently categorized across presidencies. But that does not change the reality: presidents consistently deliver diminished outcomes in their second terms. Even if we accept or would expect reduced performance in second terms, such a result has become persistent and significant enough to prompt the questions: What reasons exist for valuing first and second terms equally, i.e., keeping their lengths the same? Do the actual results produced by retaining equal four-year terms constitute not just an acceptable price but a fixed price to pay for our democracy?

\section{WHAT TO DO ABOUT SECOND TERMS IN THE TWENTY-FIRST CENTURY?}

Improving the poorer quality of second terms continues to capture the interest of scholars, journalists, political junkies, civic activists, lawyers, and politicians. It has theoretical and practical governing elements, even though its constitutional constraint seems to make it more the former. As second-term issues persist, proposals to repeal the Twenty-second Amendment or shift to a single, longer term-thought experiments in their own right today-are likely to reappear in the years ahead. Rather than pursue these failed proposals, however, we should entertain new approaches. In sum, with regard to repealing the Twenty-second Amendment, I agree with Thomas Cronin, Michael Korzi, and others that it should not happen. The problems with second terms may be exacerbated by term limits, but they are not necessarily caused by them. As term-limit defenders and presidential historians point out, many presidents before World War II also had disappointing second terms, or "secondtermitis," as Cronin said. ${ }^{74} \mathrm{He}$ called the amendment "an imperfect yet increasingly acceptable solution," "a practical compromise between the need for Hamiltonian energy and continuity on the one hand and republican and democratic principles on the other." ${ }^{75} \mathrm{He}$ added that "the two-term limit encourages fresh ideas and helps prevent the hardening of political arteries." ${ }^{76}$ These are arguments I think likely to prevail. Similarly, I think the case against a longer single term also will prevail. Despite the compelling reasons for the idea's periodic resurgence, they will not overcome the basic case, well argued by Schlesinger and others, that the presidency benefits from the connection, accountability, and incentive realized through reelection.

Other ideas to address the presidency's structural deficiencies have been put forth over the years. Some have argued for a four-year election cycle, with House terms doubled to four years and Senate terms either increased to eight years or decreased to four. ${ }^{77}$ The goal would be to elect the Congress at the same time as the president in order to provide greater executive and legislative unity. ${ }^{78}$ Four years, however, is probably too long between elections for representatives and too short for senators. Paul proposed amending the Twenty-second Amendment's limit to three terms rather than two. ${ }^{79}$ While this suggestion would likely reduce a second term's lame-duck quality, it could merely postpone lame-duck status to a subsequent termassuming some particularly successful presidents would run for and win third terms-when a president could be more tired, less concerned about the voters, and more likely to get into mischief. And, as will be discussed below, it would do nothing to address the critical problems stemming from the fact that reelection is now decided at only four years into a presidency.

Among the more interesting proposals is Larry Sabato's, which recognized the value of both increasing the time between elections and varying

\footnotetext{
${ }^{73}$ Norman J. Ornstein, The Curse of the Six-Year Itch, ATLANTIC Mon., 1, 3 (March 1986), <http://www.theatlantic.com/ past/politics/polibig/ornstein.htm>

${ }^{74}$ Thomas E. Cronin, Con: Resolved, the Twenty-Second Amendment Should Be Repealed, in Debating the PresiDENCY 60 (Richard J. Ellis and Michael Nelson eds., 2010).

${ }^{75} \mathrm{Id}$. at 63 .

${ }^{76}$ Cronin, supra note 11

${ }^{77}$ Arthur M. Schlesinger, Jr., The Constitution and Presidential Leadership, 47 MD. L. Rev. 54, 57 (1987).

${ }^{78}$ Am. EnTERPrise Inst., supra note 14, at 8; Lloyd N. Cutler, Party Government Under the Constitution (1985), in REFORMING American Government supra note 34, 104-105 (1985). ${ }^{79}$ Paul, supra note 4, at 1097-1104.
} 
presidential term lengths. In 2007 he proposed three-year terms in the House and presidential terms of six and then two years. However, his two-year second term would complicate matters by producing an eight-year, two-term presidency that does not match his three-year legislative election cycle. Sabato's solution called for irregular congressional terms and elections when presidents earn a second term, and he further complicated his proposal by advocating that presidents extend their terms not by reelection but by referendum in the fifth year. ${ }^{80}$ The math simply doesn't work cleanly, and the multiple and differing kinds of steps make this proposal too complicated for a national, public electoral process.

Finally, there remains the option of doing nothing, a view grounded more in defense of the Constitution as it is or support for our republican institutions and their still-human (i.e., faulty) character than in opposition to any one specific reform. Schlesinger joined Hallenbach and others in articulating such views and elaborated upon them in 1987. After citing Justice Brandeis, who lauded our system for being designed "not to promote efficiency but to preclude the exercise of arbitrary power," he suggested that the nation's challenges were not a problem of the separation of powers and that "the question in short is not failure of structure but failure of consensus.... A competent president with a sensible policy... has the resources under the present Constitution to get his way." ${ }^{81}$ Any number of presidents, if not all or most, would no doubt disagree. And while change for change's sake can be worth resisting, and certain inefficiencies in our system of government should be tolerated if not celebrated (especially during the Trump presidency; more about that later), the problems caused by presidential reelection after four years need not be so readily accepted.

\section{THE HEART OF THE MATTER: PRESIDENTIAL REELECTION AFTER FOUR YEARS IS NOW FUNDAMENTALLY FLAWED}

The U.S. Constitution mandates elections for president every four years (although reelection for incumbents, should it occur, comes after just three years and nine-and-one-half months of service). This interval for reelection may have been adequate prior to the advent of the modern presidency, the passage of the Twenty-second Amendment, the emergence of the permanent campaign, and a variety of other societal and technological changes since World War II (e.g., the ease of air travel and multiple revolutions in communications technology). But four years no longer makes sense for the country's most important political relationship between citizens and their national leader. Although I do not agree with Buchanan's view that "the mass public ... has recently seemed capricious in its use of this power ... to decide whether a president returns to office," 82 four years no longer seems to meet the people's needs for fulfilling their civic responsibility to assess the incumbent's suitability for continuing in office.

First, the president's first term is squeezed on both ends; its first nine months are governed by the predecessor's budget, ${ }^{83}$ and the last two years are dedicated to campaigning for reelection-his own and that of his party's representatives. ${ }^{84}$ Even 40 years ago, as the permanent campaign was emerging, William Simon lamented that the president's first term is not really four years but "a year and a half." ${ }^{85}$ A president is challenged, therefore, to create a sufficient governing record to provide voters with a basis for making a reliable, collective vote on his or her tenure. Second, there are the extensive general advantages of incumbency, which, prior to the six-year itch, make it harder to reject a sitting president than to elect a challenger. In addition to having built-in public visibility, incumbents can signal their ability to serve in the office by simple virtue of having occupied it. Reelection is seen as a contest that is theirs to lose, even if they are forced to rely on "better the devil you know" appeals.

Third, there would seem to be an inclination on the part of the American people to support the

\footnotetext{
${ }^{80}$ Larry J. Sabato, A More Perfect Constitution 87-93 (2007).

${ }^{81}$ Schlesinger, MD. L. Rev., supra note 77, at 56, 62.

${ }^{82}$ Buchanan, supra note 7 , at 130 .

${ }^{83}$ E-mail exchange with former Rep. Donald M. Fraser (June 19-22, 2008) (on file with author).

${ }^{84}$ Brendan J. Doherty, The Rise of the President's Permanent CAMPaign 42-88, 150-153 (2012). SABAto, supra note 80 , at $77-84$.

${ }^{85}$ Wicker, supra note 34 , at 5 .
} 
incumbent, as Mayhew identified. In addition to his points about risk aversion and inertia cited above, he suggested that voters were mindful of the "perceived start-up costs" a victorious opponent would have to incur (and put the nation through). ${ }^{86}$ More generally, I would add that voters could want to validate their decision of four years ago, give the incumbent a chance-in tacit recognition that the evaluation period is short-or simply satisfy a desire for stability (akin to risk aversion). These are not necessarily bad motives, but when acted upon after four years, the balance tilts decidedly toward reelection when a more even-handed or even critical baseline approach would better serve the country.

Fourth, the incumbent's edge has been strengthened even further by the permanent campaignceaseless electioneering as well as electoral considerations being paramount in decisions about governing - which emerged in the last quarter of the twentieth century. The rise of the permanent campaign and its many ill effects on governing have been examined, for example, by Sidney Blumenthal in 1982, Norman Ornstein and Thomas Mann in 2000, and Brendan Doherty in 2012. ${ }^{87}$ Doherty, in particular, documented the steady rise in presidential campaigning and fundraising activity since 1976, which has seriously encroached on the president's time, "his most precious resource." 88 Prospective opponents face a daunting challenge to overcome this time-and-platform advantage, particularly as the lines between governing and campaigning continue to blur. Donald Trump took just the latest step in extending the permanent campaign by launching his 2020 reelection campaign organization on his inauguration day, more than two years earlier than his two immediate predecessors. ${ }^{89}$

(There are non-constitutional steps that could be taken to reduce presidential campaigning relative to governing, but they are beyond the scope of this article. It bears noting, however, that a president under this proposal would face two elections during his tenure [one midterm and one reelection campaign] rather than three now [two midterms and one reelection campaign]).

We cannot and should not expect either politicians or electoral democracies to remove politics from governing. As Clark Clifford observed, "the notion that a President should be above politics [is] inconsistent with our system of government.... A President above politics is a President remote from the processes of government and removed from the thoughts and aspirations of his people." 90 One can still agree with these sentiments but also believe that the demands of electoral politics, if they end at all, start again too soon after the race is won, take up an inordinately large share of a four-year term, and provide the incumbent a consequentially enhanced advantage over any and all challengers.

The combination of these factors increases the likelihood of presidential reelection after four years, as has been borne out since World War II. Clarifying this new normal is aided by recalling the service of the three presidents out of eleven who did not win four more years when they tried. Not surprisingly, economic conditions were a factor in Jimmy Carter's and George H.W. Bush's failed attempts (much as they were in the case of Carter's most immediate one-term predecessor, Herbert Hoover). But Carter, who could not quite lead the country he was elected to heal, bears a distinction even his contemporaries, Gerald Ford and Bush I (as well as Hoover), do not hold; he became the first defeated incumbent since Grover Cleveland in 1888 whose predecessor was from the other party (and Cleveland somewhat redeemed himself by regaining the White House in 1892). On the other hand, Ford and Bush I arguably were rejected in part because their predecessors were of the same party; Ford could not escape the hangover from Nixon's failed presidency, and Bush I, even though he succeeded the popular Ronald Reagan but ran a poor campaign, nonetheless represented years nine through twelve of a Republican White House. Americans may exhibit national political patience at four years (excepting Carter), but they find it harder to sustain their support after two additional terms of one party's leadership.

\footnotetext{
${ }^{86}$ Mayhew, supra note 59, at 216.

${ }^{87}$ Sidney Blumenthal, The Permanent Campaign (1980). Norman Ornstein and Thomas Mann, The Permanent CAmpaign And Its Future (2000). Doherty, supra note 84. ${ }^{88}$ DoherTy, supra note 84 , at 16.

${ }^{89}$ Fredreka Schouten, President Trump Seizes on Election Rules to Push His Agenda in New Ways, USA Today, May 7, 2017, $<$ https://www.usatoday.com/story/news/politics/2017/05/07/ president-donald-trump-uses-election-laws-to-push-agenda/ $101262288 />$

${ }^{90}$ Wicker, supra note 34 , at 9.
} 
Indeed, Americans lose their patience after just two additional years following their vote to reelect a president. Thirty years ago, Kevin Phillips characterized the second midterm election, in which the people predictably repudiate the president, as the "six-year itch" election. He noted that "over the last half century, U.S. voters have invariably found themselves beginning to sour on administrations after six years." 91 The symptoms of this reelection paradox - in which the party in the White House wins reelection, even by a landslide, and then suffers heavy losses in congressional elections just two years later-not only have persisted but have grown more troubling in recent decades. The public's behavioral consistency-reelect after four years and repudiate after six-reveals the present structure's flaws and what has become a predictable display of excess inefficiency. Since World War II, the party of six of the seven presidents who have faced a six-year-itch election has lost seats in the election. $^{92}$ The one exception occurred in 1998, when Bill Clinton ironically benefited from the public's rejection of a baldly partisan impeachment effort by congressional Republicans. ${ }^{93}$ This paradox's roots, however, are not modern; since the Civil War, the president's party has never gained Senate seats in the midterm elections following an incumbent president's reelection, ${ }^{94}$ and it has only happened once in the House. ${ }^{95}$

This six-year itch is only paradoxical because the presidential term length happens to be four years; if the first term were six years, there would not be a paradox but synchronization. Were there no alternative to a four-year term, or were the outcomes of voting after four years not as predictable and diminishing, perhaps we could rationalize these failings away and tolerate lesser performance during half of all two-term presidencies. Again, retaining the existing structure has its supporters. Such a position, however, means that the country must pay a high price for persisting with a legislative referendum on a president who has been reelected just two years prior. Is the voters' opportunity to chasten the president and express buyers' remorse so valuable? If the second midterm election truly has become a referendum on the president that is marked by negative voting and constitutes a "presidential penalty," 96 why not include the president in that election and reconsider the suitability of reelection after four years, even in the interest of less inefficiency?

\section{DIFFERING TERM LENGTHS CAN MITIGATE LAME-DUCK PROBLEMS}

I propose that we retain the Twenty-second Amendment's limit of two terms for the president but change the length of the first term to six years and the length of the second term to three years. Implementing such a plan requires a three-year election cycle-desirable in its own right (and a topic for another time) - and two legislative structural changes: terms in the House would be three years in length instead of two, and the Senate would require a brief period of transition to be able to elect half the body every three years rather than onethird of the body every two. A deeper examination of the effects of these legislative changes is beyond the scope of this article. However, in sum, for the House, I would contend that the effects of extending terms by fifty percent would be positive (and it bears noting that James Madison successfully advocated for three-year terms for representatives at the Constitutional Convention, and they were initially adopted; later, a vocal minority in favor of single-year terms proposed the two-year term compromise that prevailed ${ }^{97}$ ). Electing half the Senate every three years would not likely have an appreciable effect on the chamber's stability, but that is a supposition that warrants further research (see the next section).

As for the four-year presidential term, Korzi said in 2014 that "there is nothing sacred about" it. ${ }^{98}$ Similarly, Buchanan wrote that "there is nothing sacrosanct about a four-year term, other than the fact that the nation has grown accustom [sic] to it." ${ }^{99}$ Furthermore, there are no substantive reasons why presidential terms have to be the same length, as Sabato's proposal demonstrated. ${ }^{100}$ Tradition

\footnotetext{
${ }^{91}$ Phillips, supra note 1.

${ }^{92}$ Franklin, supra note 65, at 25 (for results prior to 2014). David McCabe, Obama Has Lost Nearly 70 House Seats Since Taking Office, THE HiLl, Nov. 5, 2014, <http://thehill.com/ blogs/ballot-box/house-races/223047-obama-has-lost-nearly-70house-seats-since-taking-office> (for 2014 results).

${ }^{93}$ Cook, supra note 52.

${ }^{94}$ Shogan, supra note 2, at 95.

${ }^{95}$ Cook, supra note 52.

${ }^{96}$ Andrew E. Busch, Horses in Midstream: U.S. MidTerm Elections and Their Consequences 5 (1999).

${ }^{97}$ Charles O. Jones, Every Second Year: Congressional Behavior And the Two-Year Term 5 (1967).

${ }^{98}$ KorZI, supra note 8 , at 5 .

${ }^{99}$ Buchanan, supra note 7 , at 137.

${ }^{100}$ SABATO, supra note 80 .
} 
and historical uniformity carry considerable social and political weight, which I do not dismiss, but they do not constitute requirements. My proposal accepts the main premise behind a single six-year term, i.e., that it would be long enough for a president to achieve accomplishments of note. It also accepts the main arguments against such a single term, i.e., that reelection is a democratic necessity and the best-available instrument to provide a connection with the people, to present an incentive for good behavior, and to ensure accountability. Most importantly, it would synchronize the presidential term with evident voter behavior at the six-year itch (hereafter, benchmark), so that the length of the term would match the public's apparent readiness, ability, attentiveness, or even preference for evaluating the chief executive (and see the relevant items concerning voting behavior in the further research section). This proposal suggests a structural change to reflect the reduced presidential performance in and corresponding expectations from second terms. (Adjusting term lengths may not be the only way to reflect tangibly the different values of first and second terms-in a manner relatively easily implemented once decided-but I am not yet aware of alternatives.)

With regard to the second term being "just" three years long, such a period would have additional advantages. First, three years-half as long as the first term-reasonably reflects the second term's value relative to the first term. Second, three years would be long enough to constitute a meaningful bonus for a job done well. Third, and perhaps most consequentially, the second term would become truly optional rather than automatically sought. If the incumbent has done well enough not to lose the country's support at the six-year benchmark, he or she could pursue reelection to complete initiatives not concluded in the first term. If the people's support were less clear, he or she might still run, but would do so without the prop of the public's apparent inclination to support reelection at four years. Finally, if the public had clearly turned against the incumbent, he or she could choose not to run. Given every politician's sense of self or purpose this choice may seem unlikely, but the country would be better served if it did not require severe national distress to prompt a president to decide not to seek reelection, as occurred with LBJ because of his divisive Vietnam War policies. Nor should being a one-term president automatically carry the stigma of failure, as is the case now; a six-year first term could help overcome that. A president who wins reelection at six years also would have a stronger mandate for his or her second term, simply because it occurred at the six-year benchmark.

This proposed structure has additional potential benefits. Notably, a two-term president would be a lame duck for only one-third of his or her presidency instead of one-half-a consequential difference for an executive with such time-constrained power. There would still be midterm elections in Congress during a president's first term, preserving an existing checks-and-balances dynamic between the legislative and executive branches. But such elections would not occur during a second term, lessening further its lame-duck quality. Additionally, a president's maximum term of service would rise by only a single year, from eight to nine years. That really is not much, particularly given the nation's fast-paced culture, the encroachment of the permanent campaign, and the fact that any two-term president would have won his or her second term by facing the voters at the six-year benchmark. Lastly, and importantly, this proposal is structural, nonpartisan, and nonideological, and requires no regulations to administer, enforce, or try to get around.

One slight wrinkle is that a presidential challenger would be running for his or her own sixyear first term while the incumbent would be running for just three more years. This situation could muddy the voters' view of each candidate's interests, proposals, and opportunities after the election. However, the candidates competing for non-equal term lengths would not likely be a consequential factor, as continuity or change would be uppermost in the voters' minds. I suspect that citizens would be more concerned about the contest between the candidates' service and program proposals. If voters wanted to continue the incumbent's policies and leadership, they would vote for the incumbent. If they wanted a change and/or supported the challenger's policies, they would vote for the challenger.

With or without reelection, would a six-year term simply be too long? History suggests not. David Crockett reported in 2008 that, since 1789, the nation has seen, on average, 3.45 presidents every 20 years; 
accordingly, the 3.33 presidents per 20 years that would occur with a single six-year term would be "very close to the historical reality." ${ }^{101}$ Would we risk having to put up with two "extra" years of a poor, inept or malevolent president? In 2013, constitutional scholars Thomas Cronin, Louis Fisher, and Sanford Levinson expressed such cautionary views, ${ }^{102}$ and the election of Donald Trump raises it explicitly. However, this risk can be discounted, offset, or adequately overcome. First, Americans have demonstrated their comfort with occupants of the White House serving for more than four years, even if poor campaigns by challengers effectively made them appear the lesser of two evils. The history Crockett documented bears this out, as does recent experience; to remind, voters have affirmed the wishes of eight of the last eleven incumbents who have sought four additional years. Accordingly, two additional years during a first term may not represent that much of an upheaval. Consider again the three presidents denied a second term since FDR. Few people would argue that two more years of the Ford and Bush I presidencies would have been particularly bad for the country, but some might argue that the Carter presidency exemplified this risk, although the potential partisanship of such critiques must be acknowledged. The risk of electing an intolerably poor president will always exist (and may have happened in 2016), but history suggests it is rare.

Second and most importantly, the risk of giving two additional first-term years to a "poor" president is actually offset by the fact that voters can reelect as well as reject such presidents-and they have done so. In such cases, if the vote to reelect occurred after six rather than four years, the nation could avoid the seventh and eighth years in office of a poor twoterm president who otherwise might be reelected after four years. President George W. Bush exemplifies this counterbalancing risk; had he stood for reelection in 2006 rather than 2004, a good case can be made that he would not have been reelected because of his response to Hurricane Katrina and declining support for the war in Iraq. ${ }^{103}$ Ultimately, arguments about the risk of two extra years of a bad one-term president or the benefit of two fewer years of a bad two-term president are speculative and, again, hard to separate from partisan bias. But their offsetting nature diminishes their role in calculating the merits of a four- vs. a six-year first term.

\section{OTHER POTENTIAL BENEFITS, UNINTENDED CONSEQUENCES, AREAS FOR FURTHER RESEARCH, AND THE TRUMP EFFECT}

This proposal for a three-year election cycle anchored by new presidential term lengths would produce changes extending well beyond the timing for presidents' election and reelection. Even the plausible potential benefits are still only hypothetical, and there would be unintended consequences. Here are a few of both, to be vetted in further research:

- Are there any viable means-and, perhaps most importantly, schedules-for having a referendum, recall, or other sub-impeachment method to remove a malevolent or incompetent president who neither commits an impeachable offense nor acts in an incapacitated manner as envisioned under the removal provisions of the Twenty-fifth Amendment? (Congressman Henry Reuss offered such a plan in 1975, having concluded after Watergate that a nonimpeachment alternative to remove a president was needed, but it proved too complicated and likely would not have saved much time. ${ }^{104}$ )

- What would be the effect of adding a year between elections? Would it relieve the debilitating impact of voter fatigue in our civic life, or have little or no effect? Would Americans,

${ }^{101}$ Crockett, supra note 57, at 715 .

${ }^{102}$ E-mail from Thomas E. Cronin, McHugh Professor of American Institutions and Leadership, Colorado College, to author (July 29, 2013) (on file with author); Interview with Louis Fisher, Scholar in Residence, the Constitution Project, and former Specialist in Constitutional Law, the Library of Congress, Silver Spring, MD (May 15, 2013); E-mail from Sanford V. Levinson, W. St. John Garwood, and W. St. John Garwood, Jr. Centennial Chair in Law, University of Texas Law School, to author (May 4, 2013) (on file with author).

${ }^{103}$ Dan Balz and Michael Abromowitz, President Tries to Win over a War-Weary Nation, WASH. PosT Sept. 12, 2006, <http:// www.washingtonpost.com/wp-dyn/content/article/2006/09/11/ AR2006091101416.html>.

${ }^{104}$ Henry Reuss, A Congressional Vote of No Confidence (1975), in Reforming American Government, supra note 34, at 206-208. See also Allan Sindler, A Critique of the Reuss Proposal (1975), at 223, and Samuel Beer, The British Experience (1975), at 220, in REFORMING AMERICAN GOVERNMENT, supra note 34. 
whose average lifespan is 79 , relish or resent voting for Congress and president only 20 times in their lifetimes versus 30 times now?

- Would our national elections, by being farther apart, assume more importance and thereby attract increased citizen engagement? By voting less often, would citizens take their civic obligation more seriously? Would voter turnout in less frequent non-presidential election years rise at all or stay appreciably lower than in presidential election years?

- Would relief from ceaseless campaigning give disaffected voters one less reason they could use to rationalize remaining disengaged from their civic duty?

- Would two extra years in a presidential first term add to the uncertainty Ragsdale and Rusk identified as a factor that increases turnout? ${ }^{105}$

- Would shifting Senate elections to half the body every three years rather than one-third the body every two diminish to any extent the desired stability of the upper chamber?

- For those in office, would an additional year between elections reduce the seeming immediacy of the next election, which prompts obstructionism by the majority as well as the minority? Could it enable the value as well as the art of compromise to regain lost ground, or would the extra twelve months make no difference?

- Would the partisans who lost an electionwhich could be close to half of the electoratebe able and willing, as Brendan Doherty has worried, to wait six years for their next shot at the White House? ${ }^{106}$

- And how would the changed national election schedule interact with state and local election schedules? What are the pros and cons of removing the synchronization (if states don't adjust their schedules) or making the adjustment to retain it? What lessons can we learn, pro and con, from the five states, including Virginia and New Jersey, and the cities, including Los Angeles and New York City, that already follow a non-synchronized schedule?

Less prospectively, all elected officials would gain more time to attend to the nation's business under this structure. If national elections were held every third year rather than every second year, we might not see 50 percent less campaigning, but we would see less. Clearly, campaign activity, particularly fundraising, would creep into these extra twelve months, but just how much is uncertain. Even when viewed conservatively, however, the time saved should be considerable: if we gained as little as one-third the time, or just four extra months per cycle, we would still save more than a year each decade, or a decade each century. If only for these tangible benefits of months and years saved-by citizens as well as or even more so than those who govern them-a three-year election cycle merits consideration.

Finally, it is hard enough to contemplate a thought experiment requiring amending the Constitution (see next section), but we also find ourselves in the first term of a polarizing incumbent who has the lowest approval ratings of any modern president at this stage of his tenure. That four years of President Trump could be six years instead under this proposal is off-putting on its face to many people. Still, we can only speculate on the impact of the Trump presidency on this election-cycle proposal. It could be any number of the following:

(a) The clearest example imaginable of the reason to keep a president's first term at "just" four years. This effectively is the case made by Ben Carson, who endorsed Trump in March 2016 and said, "Even if Donald Trump turns out not to be such a great president... we're only looking at four years ... "107;

(b) Evidence that the system works. A presidency like Trump's is the rarest of cases that the nation's founders nonetheless envisioned and protected against by designing an inefficient system of checks and balances that, at this writing, seems to be holding;

(c) Irrelevant, accordingly, as the gears of our constitutional system work either to constrain his worst behavior or to remove him from office through available means;

${ }^{105}$ Lyn Ragsdale and Jerrold G. Rusk, The American NoNVOTER 1-26 (2017).

${ }^{106}$ E-mail from Brendan J. Doherty, Associate Professor of Political Science, United States Naval Academy, to author (June 13, 2014) (on file with author).

${ }^{107}$ Ben Carson, when endorsing Donald Trump on March 15, 2016 (see, for example, <http://www.huffingtonpost.com/entry/ ben-carson-donald-trump-only-four-years_us_56e7974ae4b0b25c 91831fa3>). 
(d) An example of the nation's need to articulate a wider range of ways to remove a president based on reasons neither explicitly nor implicitly captured by impeachment (as expressed in Articles I and II of the Constitution) or incapacity (as expressed in the Twenty-fifth Amendment);

(e) A necessary prod for both the people and our institutions to take civic education and participation much more seriously. The fact that more people choose not to vote in presidential elections than support the winner is difficult to reconcile with any definition of a vital democracy; and/or

(f) Another reason to extend the first term to six years. Trump could be reelected after four years, as it is by no means assured that the Democrats will present a candidate who could defeat him. Nor is it clear that impeachment could succeed if the Democrats retake the House in 2018. Trump winning his reelection bid in 2020 could in fact strengthen the case that four years is no longer an appropriate amount of time for the public to assess both the incumbent and his competition. This is the flip-side of Ben Carson's argument and a variant on the concern that voters do not see that their votes matter or that four years is a meaningful, serious, or even risky enough amount of time to compel their attention, concern, and participation. Would citizens take their civic duty for presidential elections more seriously if the first term were six years in length rather than four?

Considering such longer term, structural issues at such a fraught political time does remind us, however, that the chaos, incompetence, and venality of the Trump presidency will soon be in our past. I share the hope expressed by Tulis that Trump "may help awaken a watchful people." ${ }^{108}$ Similarly, Dionne, Ornstein, and Mann have suggested that "the popular mobilization and national soul-searching he has aroused could be the occasion for an era of democratic renewal." ${ }^{109}$ Whether Trump serves for two, four, or eight years, the nation will survive and move on after him. Hopefully, any damage he will have wrought will prove short-lived, will not be as bad as feared, and, perhaps most importantly, will not have been normalized. Our system of checks and balances could prove to have worked and our citizens and other public officials may have effectively limited the negative impact of his reckless or non-presidential behavior.

\section{AMENDING THE CONSTITUTION}

Ultimately, any change to presidential term lengths must overcome its constitutional hurdle. The proposal I have presented here is still only an idea (and the core component of my forthcoming book), so it is premature to consider it a formal amendment proposal. The idea must be aired, vetted, and debated first. The political environment also would have to change. For example, dissatisfaction with lame-duck second terms or the permanent campaign would have to increase, or other electoral reforms addressing these and related issues would have to be adopted and either succeed or fail, thereby prompting the public and its leaders to look elsewhere for new solutions to political problems. Such constitutional change could not occur in a vacuum.

That said, constitutional amendments were intended for just this kind of structural improvement of our government. Since the Bill of Rights was passed, two-thirds of the adopted amendments have changed elections, voting rights, or electoral service, ${ }^{110}$ and no less than five of these have involved structural changes to the presidency. ${ }^{111}$ Still, Joseph Kallenbach's observation from 1970 remains true today: "the prospects appear to be practically nil" to effect changes to the presidency via constitutional amendment. ${ }^{112}$

It is unfortunate, in fact, that the already-difficult amendment process has been trivialized in recent decades by amendment campaigns for or against procedural or social issues, such as balancing the budget or burning the flag. Perhaps we should not be surprised that the lessons of Prohibition - that attempts to advance a non-structural idea or non-fundamental right

\footnotetext{
${ }^{108}$ Tulis, supra note 48, at 237.

${ }^{109}$ E.J. Dionne, Jr., Norman J. Ornstein, and Thomas E. Mann, One Nation After Trump 3 (2017).

${ }^{110}$ U.S. CONST. AMEND. XI-XXVII.

${ }^{111}$ Joseph E. Kallenbach, The Presidency and the Constitution: A Look Ahead, 35 Law and Contemp. Problems 445, 445 (Summer 1970).

${ }^{112} I d$. at 449 .
} 
do not belong in the Constitution-have been forgotten. There is a civic imperative to restore the legitimacy of the amendment process, irrespective of one's views of the process's difficulty. One need not embrace Levinson's call for a Constitutional Convention to acknowledge the kernel of truth in his charge that "we must recognize that a substantial responsibility for the defects of our polity lies in the Constitution itself." 113 And no matter what one thinks of Sabato's multiple proposals for constitutional amendments in A More Perfect Constitution, he, too, has a point in asserting that "the failure of the nation to update the Constitution and the structure of government it originally bequeathed to us is at the root of our current political dysfunction." 114 The nation can and should entertain amendments that address structural weaknesses or fundamental rights. If a viable alternative structure for the presidency exists, should constitutional constraints prevent us from contemplating if not pursuing its potential benefit?

\section{CONCLUSION}

After more than two centuries, the four-year term of office for the president may well have run its course. Reelection after four years to a second and final term produces too many governing problems and no longer makes sense. I argue that the value of second terms is consistently and sufficiently less than that of first terms and so, accordingly, second terms should not have the same length as first terms. Further, the public's relationship to the office, governing efficiency, improved public service, and the need for a structural brake on the relentless permanent campaign call for reelection after six years, but to a shorter, bonus period. This proposal will not solve all of the problems confronting U.S. politics as the nation approaches its quarter millennium. The 2016 presidential primaries provided ample reasons to pursue non-constitutional change to the nominating process, and the ill effects of the Trump presidency will have to be unraveled. Other nonconstitutional issues of governing dysfunction and hyper-partisanship demand attention. More explicitly, election reform efforts will understandably remain focused on voting rights (of primary concern), the gerrymander, campaign finance, and international influence. Ultimately, however, correcting for the inadequacy of presidential reelection after four years will merit attention and action.

\section{ACKNOWLEDGMENTS}

I acknowledge in particular Brendan Doherty, David P. Cohen, Lou Fisher, and anonymous reviewers for their contributions to this work.

\section{REFERENCES}

Achens, Christopher H. and Larry M. Bartels. Democracy for Realists: Why Elections Do Not Produce Responsive Government. Princeton: Princeton University Press, 2016.

American Enterprise Institute Legislative Analyses. Limiting Presidential and Congressional Terms. Washington: American Enterprise Institute, 1979.

Balz, Dan and Michael Abromowitz. "President Tries to Win over a War-Weary Nation." Washington Post, Sept. 12, 2006. <http://www.washingtonpost.com/wp-dyn/content/article/ 2006/09/11/AR2006091101416.html>.

Beer, Samuel. "The British Experience.” In Robinson, Reforming American Government, 215-221.

Bell, Griffin et al. "For a One-Term, Six-Year Presidency." New York Times, December 31, 1985. <http://www.nytimes.com/ 1985/12/31/opinion/for-a-one-term-six-year-presidency .html>.

Blumenthal, Sidney. The Permanent Campaign. New York: Simon \& Schuster, 1982.

Buchanan, Bruce. "The Six-Year One Term Presidency: A New Look at an Old Proposal." Presidential Studies Quarterly 18 no. 1 (Winter 1988): 129-142.

Busch, Andrew E. Horses in Midstream: U.S. Midterm Elections and Their Consequences. Pittsburgh: University of Pittsburgh Press, 1999.

Carson, Ben. Comment when endorsing Donald Trump on March 15, 2016 (see, for example, <http://www.huffington post.com/entry/ben-carson-donald-trump-only-four-years_us_ 56e7974ae4b0b25c91831fa3>).

Cook, Charlie. "Six-Year Itch Plagues Presidents in Midterms." National Journal, January 6, 2014. <https://www.national journal.com/daily/2014/01/06/six-year-itch-plagues-pre sidents-midterms $>$.

Crockett, David A. “'An Excess of Refinement': Lame Duck Presidents in Constitutional and Historical Context." Presidential Studies Quarterly 38 no. 4 (December 2008): 707721.

Cronin, Thomas E. "Presidential Term, Tenure and Reeligibility." In Inventing the American Presidency, ed. Thomas Cronin, 61-88. Lawrence: University Press of Kansas, 1989.

. "Con: Resolved, the Twenty-second Amendment Should Be Repealed.” In Debating the Presidency, 2nd ed. eds. Richard J. Ellis and Michael Nelson, 56-63. Washington, DC: CQ Press, 2010.

\footnotetext{
${ }^{113}$ Sanford Levinson, Our Undemocratic Constitution: Where the Constitution Goes Wrong (and How We the People Can Correct It) 9 (2006).

${ }^{114}$ SABATO, supra note 80 , book jacket.
} 
_. "Term Limits Are a Check Against an American Cult of Personality." Washington Post, January 3, 2014. <https:// www.washingtonpost.com/opinions/term-limits-are-a-checkagainst-an-american-cult-of-personality/2014/01/03/270d 3034-6374-11e3-aa81-e1dab1360323_story.html>.

Cutler, Lloyd N. "Party Government Under the Constitution." In Robinson, Reforming American Government, 93-109.

Diller, Daniel C. "Chief of State." In Nelson, Guide to the Presidency, 3rd ed., Vol. 1, 687-716.

Dionne, Jr., E.J., Norman J. Ornstein, and Thomas E. Mann. One Nation After Trump. New York: St. Martin's Press, 2017.

Doherty, Brendan J. The Rise of the President's Permanent Campaign. Lawrence: University Press of Kansas, 2012.

Farrand, Max. The Framing of the Constitution of the United States. New Haven: Yale University Press, 1913.

Fortier, John C. and Norman J. Ornstein, eds. Second Term Blues: How George W. Bush Has Governed. Washington, DC: American Enterprise Institute and Brookings Institution Press, 2007.

Franklin, Daniel P. Pitiful Giants: Presidents in Their Final Terms. New York: Palgrave Macmillan, 2014.

Fraser, Donald M. Former Member of Congress. E-mail exchange with author, June 19-22, 2008. On file with author.

Gardbaum, Stephen and Richard H. Pildes. "Populism and Democratic Institutional Design: Methods of Selecting Candidates for Chief Executive in the United States and Other Democracies." New York University Law Review. (November 3, 2017; Forthcoming, 2018). Available at SSRN: <https://ssrn.com/abstract=3064938>.

Gould, Lewis L. The Modern American Presidency. 2nd ed. Lawrence: University Press of Kansas, 2009.

Halberg, Caleb J. "Power and Time: Why Anti-Federalists Feared Lengthy Presidential Terms." DePaul University College of Law (Dec. 15, 2010). At SSRN: <http://ssrn .com/abstract=1726182> or <http://dx.doi.org/10.2139/ ssrn.1726182>.

Hamilton, Alexander. "The Federalist No. 71." In The Unabridged Federalist Papers and Anti-Federalist Papers. 274-277. USA: ReadaClassic.com, 2010.

—. "The Federalist No. 72." In The Unabridged Federalist Papers and Anti-Federalist Papers. 277-281. USA: ReadaClassic.com, 2010.

Hedtke, James R. Lame Duck Presidents-Myth or Realty. Lewiston, NY: Edwin Mellon Press, 2002.

Jefferson Foundation. "The Single, Six-Year Term for Presidents." In Robinson, Reforming American Government, $167-174$

Jones, Charles O. Every Second Year: Congressional Behavior and the Two-Year Term. Washington, DC: Brookings Institution, 1967.

Kallenbach, Joseph E. "The Presidency and the Constitution: A Look Ahead." Law and Contemporary Problems 35 (Summer 1970): 445-460.

Karol, David. "Pro: Resolved, the Twenty-second Amendment should be repealed." In Debating the Presidency, 2nd ed. eds. Richard J. Ellis and Michael Nelson, 50-56. Washington, DC: CQ Press, 2010.

Korzi, Michael J. Presidential Term Limits in American History. College Station: Texas A\&M Press, 2011.

Levinson, Sanford V. Our Undemocratic Constitution: Where the Constitution Goes Wrong (and How We the People Can Correct It). New York: Oxford University Press, 2006. - An Argument Open to All: Reading the Federalist in the 21st Century. New Haven: Yale University Press, 2015.

Mayhew, David R. "Incumbency Advantage in U.S. Presidential Elections: The Historical Record." Political Science Quarterly 123, no. 2 (2008): 201-228.

McCabe, David. "Obama Has Lost Nearly 70 House Seats Since Taking Office." The Hill, November 5, 2014. <http://thehill .com/blogs/ballot-box/house-races/223047-obama-has-lostnearly-70-house-seats-since-taking-office> .

McCullough, David. Truman. New York: Simon \& Schuster, 1992.

Nathan, Richard P. The Administrative Presidency. New York: John Wiley \& Sons, 1983.

Neale, Thomas H. Presidential Terms and Tenure: Perspectives and Proposals for Change. Washington, DC: Congressional Research Service, Oct. 19, 2009.

Nelson, Michael. Guide to the Presidency, 3rd ed. Washington, DC: CQ Press, 2002.

Ornstein, Norman J. "The Curse of the Six-Year Itch.” Atlantic Monthly, March 1986. <http://www.theatlantic.com/past/ politics/polibig/ornstein.htm>.

Ornstein, Norman and Thomas Mann. The Permanent Campaign and Its Future. Washington, DC: American Enterprise Institute and Brookings Institution, 2000.

Paul, Jeremy. "If It Quacks Like a Lame Duck, Can It Lead the Free World?: The Case for Relaxing Presidential Term Limits." Connecticut Law Review 43 (May 2011): 10971104.

Peirce, Neil. "Ford's Bipartisanship: How to Keep It Alive." Houston Chronicle, January 7, 2007. <http://www.chron.com/ opinion/outlook/article/Peirce-Ideas-to-help-keep-GeraldFord-s-1808226.php $>$.

Phillips, Kevin. "Reelection Paradox: Landslide and Loss of Power." Christian Science Monitor, November 2, 1984. <http://www.csmonitor.com/1984/1102/110212.html>.

Ragsdale, Lyn and Jerrold G. Rusk. The American Nonvoter. New York: Oxford University Press, 2017.

Reuss, Henry. "A Congressional Vote of No Confidence." In Robinson, Reforming American Government, 206-208.

Robinson, Donald L., ed. Reforming American Government: The Bicentennial Papers of the Committee on the Constitutional System. Boulder: Westview Press, 1985.

Sabato, Larry J. A More Perfect Constitution. New York: Walker \& Company, 2007.

Schlesinger, Jr., Arthur. "Against a One-Term, 6-Year President." New York Times, January 10, 1986. <https:// www.nytimes.com/books/00/11/26/specials/schlesinger6year.html>.

. "The Constitution and Presidential Leadership." Maryland Law Review 47 no. 1 (1987): 54-74. 
Schouten, Fredreka. "President Trump Seizes on Election Rules to Push His Agenda in New Ways.” USA Today, May 7, 2017. <https://www.usatoday.com/story/news/ politics/2017/05/07/president-donald-trump-uses-electionlaws-to-push-agenda/101262288/>.

Shogan, Colleen J. "The Sixth Year Curse." Presidential Studies Quarterly 36 no. 1 (March 2006): 89-101.

Silver, Nate. "Is There Really a Second-Term Curse?" New York Times, May 16, 2013. <http://fivethirtyeight.blogs.nytimes .com/2013/05/16/is-there-really-a-second-term-curse/>.

Sindler, Allan. "A Critique of the Reuss Proposal." In Robinson, Reforming American Government, 222 - 226.

Skowronek, Stephen. The Politics Presidents Make. Cambridge: Belknap Press, 1993.

Summers, Lawrence. "Second-term Presidents Cost America 40 Lost Years." Financial Times, August 10, 2014. <http://www .ft.com/cms/s/2/74dacab2-1e3e-11e4-ab52-00144feabdc0 .html\#axzz4EGzdta9Z>.

Suri, Jeremy. The Impossible Presidency: The Rise and Fall of America's Highest Office. New York: Basic Books, 2017.

Tulis, Jeffrey K. The Rhetorical Presidency. Princeton: Princeton University Press, 2017.
United States Constitution, Amendments XI-XXVII.

Vance, Cyrus R. "Reforming the Electoral Reforms." Yale Law \& Policy Review 1 (1982): 151-157.

Weldon, Kathleen. "The Public and the 22nd Amendment: Third Terms and Lame Ducks." Huffington Post, August 11, 2015. <http://www.huffingtonpost.com/kathleen-weldon/ the-public-and-the-22nd-a_b_7967538.html $>$.

Wicker, Tom. "Six Years for the President." New York Times Magazine, June 26, 1983. <http://www.nytimes.com/1983/ 07/31/magazine/l-six-years-for-the-president-069728.html>;

Zimmerman, Jonathan. "End Presidential Term Limits." Washington Post, November 28, 2013. <https://www.washington post.com/opinions/end-presidential-term-limits/2013/11/28/ 50876456-561e-11e3-ba82-16ed03681809_story.html>.

Address correspondence to: Rick LaRue 1602 Wilson Place Silver Spring, MD 20910

E-mail: ricklarue57@gmail.com 